\title{
Dynamic Succession of Groundwater Sulfate-Reducing Communities during Prolonged Reduction of Uranium in a Contaminated Aquifer
}

Ping Zhang, ${ }^{\dagger}$ — Zhili He, ${ }^{\dagger}$ Joy D. Van Nostrand, ${ }^{\dagger}$ Yujia Qin, ${ }^{\dagger}$ Ye Deng, ${ }^{\dagger, \nabla}$ Liyou Wu, $^{\dagger}$ Qichao Tu, ${ }^{\dagger}$ Jianjun Wang, ${ }^{\dagger}$ I† Christopher W. Schadt, ${ }^{\ddagger}$ Matthew W. Fields, ${ }^{\S}{ }^{\circledR}$ Terry C. Hazen, ${ }^{\|, \ddagger}$ Adam P. Arkin, ${ }^{\perp}$ David A. Stahl, ${ }^{\#}$ and Jizhong Zhou*, ${ }^{*}, \infty, \otimes$

${ }^{\dagger}$ Institute for Environmental Genomics, Department of Microbiology and Plant Biology, and School of Civil Engineering and Environmental Sciences, University of Oklahoma, Norman, Oklahoma 73019, United States

${ }^{\ddagger}$ Biosciences Division, Oak Ridge National Laboratory, Oak Ridge, Tennessee 37831, United States

${ }^{\S}$ Center for Biofilm Engineering, Montana State University, Bozeman, Montana 59717, United States

"Department of Civil and Environmental Engineering, University of Tennessee, Knoxville, Tennessee 37996, United States

${ }^{\perp}$ Physical Biosciences Division, Lawrence Berkeley National Laboratory, Berkeley, California 94720, United States

\#Department of Civil and Environmental Engineering, University of Washington, Seattle, Washington 98105, United States

${ }^{\nabla}$ Research Center for Eco-Environmental Science, Chinese Academy of Sciences, Beijing 100085, China

Department of Marine Sciences, Ocean College, Zhejiang University, Zhejiang, China

${ }^{\text {II }}$ State Key Laboratory of Lake Science and Environment, Nanjing Institute of Geography and Limnology, Chinese Academy of Sciences, Nanjing 210008, China

${ }^{\infty}$ Earth and Environmental Sciences, Lawrence Berkeley National Laboratory, Berkeley, California 94720, United States

${ }^{\otimes}$ State Key Joint Laboratory of Environment Simulation and Pollution Control, School of Environment, Tsinghua University, Beijing 100084, China

\section{Supporting Information}

\begin{abstract}
To further understand the diversity and dynamics of SRB in response to substrate amendment, we sequenced genes coding for the dissimilatory sulfite reductase $(d s r A)$ in groundwater samples collected after an emulsified vegetable oil (EVO) amendment, which sustained $\mathrm{U}(\mathrm{VI})$-reducing conditions for one year in a fast-flowing aquifer. EVO amendment significantly altered the composition of groundwater SRB communities. Sequences having no closely relateddescribed species dominated $(80 \%)$ the indigenous SRB communities in nonamended wells. After EVO amendment, Desulfococcus, Desulfobacterium, and Desulfovibrio, known for long-chain-fatty-acid, short-chain-fatty-acid and $\mathrm{H}_{2}$ oxidation and $\mathrm{U}(\mathrm{VI})$ reduction, became dominant accounting for $7 \pm 2 \%, 21 \pm$ $8 \%$, and $55 \pm 8 \%$ of the SRB communities, respectively. Succession of these SRB at different bioactivity stages based on redox substrates/products (acetate, $\mathrm{SO}_{4}{ }^{-2}$, $\mathrm{U}(\mathrm{VI}), \mathrm{NO}_{3}{ }^{-}, \mathrm{Fe}(\mathrm{II})$, and $\mathrm{Mn}(\mathrm{II})$ ) was observed. Desulfovibrio and Desulfococcus

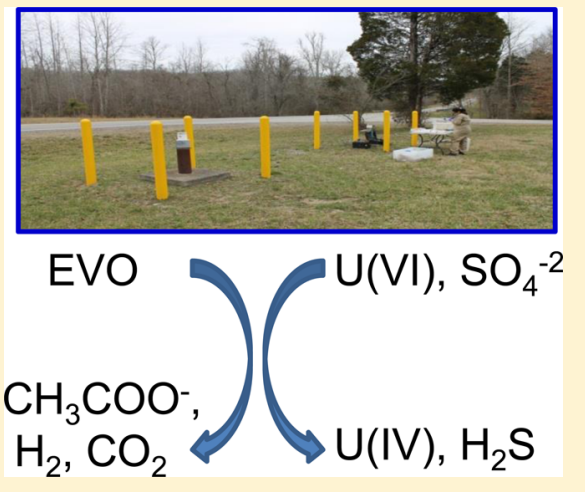
dominated SRB communities at 4-31 days, whereas Desulfobacterium became dominant at 80-140 days. By the end of the experiment (day 269), the abundance of these SRB decreased but the overall diversity of groundwater SRB was still higher than non-EVO controls. Up to $62 \%$ of the SRB community changes could be explained by groundwater geochemical variables, including those redox substrates/products. A significant $(P<0.001)$ correlation was observed between groundwater $\mathrm{U}(\mathrm{VI})$ concentrations and Desulfovibrio abundance. Our results showed that the members of SRB and their dynamics were correlated significantly with slow EVO biodegradation, electron donor production and maintenance of $\mathrm{U}(\mathrm{VI})$-reducing conditions in the aquifer.
\end{abstract}

\section{INTRODUCTION}

Groundwater contaminated with heavy metals (e.g., U(VI), $\mathrm{Cr}(\mathrm{VI})$ ) is a continuing problem at mining and nuclear facilities such as the U.S. Department of Energy's (DOE) Oak Ridge Integrated Field Research Challenge (ORIFRC), the Old Rifle uranium mill tailing remedial action, and Hanford sites. ${ }^{1}$ Microbial reduction to their insoluble forms (e.g., U(IV), $\mathrm{Cr}(\mathrm{IV})$ ) has been recognized as an effective approach to immobilize these contaminants in situ. ${ }^{2,3}$ Thus, in an effort to remediate these sites, various substrates, including acetate, ethanol, glycerol polylactate and emulsified vegetable oil (EVO), have been injected to

Received: June 14, 2016

Revised: November 21, 2016

Accepted: November 30, 2016

Published: March 16, 2017 


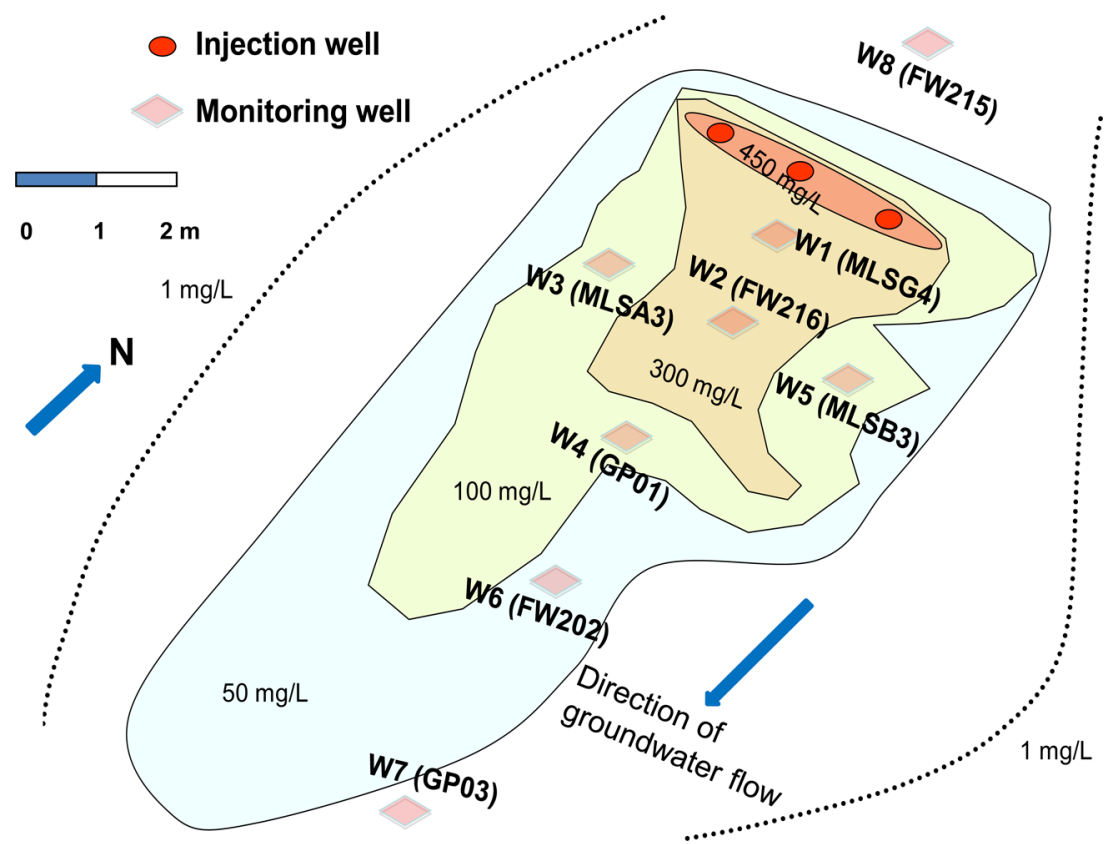

Figure 1. Well system for in situ bioremediation of $\mathrm{U}(\mathrm{VI})$ with EVO amendment, showing groundwater flow direction and distribution of a upgradient control well, W8 (FW215) and seven downgradient monitoring wells, W1 (MLSG4), W2 (FW216-1), W3 (MLSA8), W4 (GP01), W5 (MLSB3), W6 (FW202-2), and W7 (GP03). The peak bromide concentration distribution was drawn based on data from a previous tracer test with injection of bromide solution $(450 \mathrm{mg} / \mathrm{L})$ into the three injection wells as an indicator of hydraulic connection among the wells.

stimulate indigenous microbial communities toward long-term metal-reducing conditions. ${ }^{4}$ Studies over the last 10 or more years have shown that substrate amendment does stimulate microbial populations important to $\mathrm{U}(\mathrm{VI})$ reduction, such as nitrate-, Fe(III)-, and sulfate-reducing bacteria (SRB), resulting in distinct microbial communities and activities after amendments. ${ }^{5-10}$ However, the ability of these communities to maintain metal-reducing conditions was largely dependent on the choice of substrate. For example, a study using batch systems inoculated with subsurface sediment from the Rifle site found that lactate and acetate stimulated simultaneous sulfate and ferrihydrite reduction, whereas glucose only stimulated ferrihydrite reduction. ${ }^{10}$ Which SRB are responsive to amendment may also be important in maintenance of reducing conditions. ${ }^{11}$ At the Rifle site, $\mathrm{U}(\mathrm{VI})$ rebounded only 50 days after acetate amendment, as sulfate reduction became the predominant terminal electron-accepting process with growth of SRB (e.g., Desulfosporosinus, Desulfotomaculum) that do not reduce U(VI) with acetate as the sole electron donor. ${ }^{5}$ However, it was also suggested that even after U(VI) reducers such as Geobacter and SRB deplete Fe(III) oxides, SRB may continue to grow using the sulfate entering the area via groundwater flow and maintain $\mathrm{U}(\mathrm{VI})$ - reducing conditions as long as appropriate electron donors are supplied. ${ }^{5}$

Prolonged ( $1-3.5$ years) $\mathrm{U}(\mathrm{VI}) / \mathrm{Cr}(\mathrm{VI})$ reduction was later achieved with frequent or one-time amendment(s) of hydrogenrelease substrates, such as ethanol or EVO at the Oak Ridge site and glycerol polylactate at Hanford. ${ }^{6,8,9,11,12}$ These substrates stimulated Desulfovibrio, ${ }^{8,9,12}$ which are well-known U(VI)/Cr(VI) reducers when electron donors such as $\mathrm{H}_{2}$ are supplied. ${ }^{13-15}$ While many electron donors can stimulate $\mathrm{U}(\mathrm{VI})$ reduction, more complex substrates have been shown to be more effective, ${ }^{15}$ probably due to further degradation of these substrates. SRB may be involved in substrate degradation as EVO amendment stimulated Desulforegula, which are known for incomplete oxidation of long-chain fatty acids (LCFAs) to acetate and could be involved in EVO degradation and providing electron donors and carbon (C) sources (e.g., $\mathrm{H}_{2}$, acetate, $\mathrm{CO}_{2}$ ) for $\mathrm{U}(\mathrm{VI})$ reduction. ${ }^{6}$

While previous studies, primarily through $16 \mathrm{~S}$ rRNA gene analysis, have provided valuable insights into the significant association between SRB stimulation and $\mathrm{U}(\mathrm{VI})$ reduction, ${ }^{6,11,12}$ some important questions remain to be answered. A study at the Rifle site indicated Desulfobacteraceae were stimulated by acetate addition, while other SRB such as Syntrophaceae and Desulfobulbaceae were not $^{16}$ and bacteria similar to Desulfobacter postgateii and Geobacter bemidijiensis were stimulated by $U$ addition in the presence of acetate based on $d s r B$ transcripts. ${ }^{17}$ However, other studies suggest that the amount of biomass overall may be more important to $U$ removal than specific populations ${ }^{16}$ or that SRB are only indirectly involved in U(VI) reduction via production of hydrogen sulfide. ${ }^{18}$ Therefore, further in-depth analysis of SRB community changes after substrate amendment is required to understand how this important functional group of bacteria may contribute to maintaining low concentrations of $\mathrm{U}(\mathrm{VI})$ in groundwater over long time periods.

The $d s r A / B$ genes, which encode the alpha $(d s r A)$ and beta $(d s r B)$ subunits of the dissimilatory sulfite reductase involved in sulfate reduction, are suitable biomarkers for SRB as they are found in all cultured $S R B$ and the gene sequence is highly conserved. ${ }^{20}$ Sequencing of $d s r A / B$ genes following cloning or isolation by denaturing gradient gel electrophoresis (DGGE) has been used for analysis of SRB communities in various aqueous environments. ${ }^{16,21-24}$ However, recent revolutionary advances in high-throughput sequencing technology now serve for much more intensive and extensive analyses of SRB communities. ${ }^{25}$ This study was conducted at the ORIFRC site within a uraniumbearing contaminant plume. A single 2-h injection of EVO reduced groundwater $\mathrm{U}(\mathrm{VI})$ concentrations for 1 year in this fast-flowing aquifer. ${ }^{26}$ Previous analyses indicated that the amendment altered the overall phylogenetic and functional structure of groundwater microbial communities and SRB were enriched. ${ }^{6,27}$ In this study, the experimental design and EVO 
amendment were the same as the general survey of groundwater microbial communities using pyrosequencing of $16 \mathrm{~S}$ rRNA genes. ${ }^{6}$ However, we further analyzed the groundwater SRB using pyrosequencing of $d s r A$ genes. Particularly, we examined how SRB communities change with EVO amendment, and how those changes relate to the maintenance of $\mathrm{U}(\mathrm{VI})$-reducing conditions. We hypothesized that (i) EVO amendment would increase the diversity of groundwater SRB; (ii) EVO amendment would stimulate specific SRB, particularly LCFA degraders, short-chain fatty acid (SCFA) degraders, $\mathrm{H}_{2}$ consumers and $\mathrm{U}(\mathrm{VI})$ reducers to fully utilize complex EVO and its degradation products; and (iii) the different SRB groups would be stimulated at different time points after EVO amendment, and the dynamic succession of SRB would promote prolonged U(VI)-reducing conditions through slow EVO degradation, release of electron donors and carbon sources, and stimulation of U(VI)-reducing SRB. Our results showed that EVO amendment increased the diversity of SRB and enriched functional groups known to be active in EVO degradation and U(VI) reduction, providing important mechanistic insights on how SRB succession promotes prolonged $\mathrm{U}(\mathrm{VI})$-reducing conditions.

\section{MATERIALS AND METHODS}

Site Description, EVO Amendment, and Sampling. A detailed description of the experimental site, design, and sampling was published previously ${ }^{6,26}$ and is provided in the Supporting Information (SI). Briefly, this study was conducted in Area 2 of the ORIFRC (https://public.ornl.gov/orifc/orfrc1_fieldchallenge. $\mathrm{cfm})$. The groundwater flows from an upgradient zone across a control well (W8) and three injection wells, and then passes through the downgradient zone installed with seven monitoring wells (W1-W7) (Figure 1). Prior to the experiment, the groundwater flow pattern was characterized and peak bromide concentrations detected indicated hydraulic connection among the wells. ${ }^{6}$ Dissolved oxygen was near zero, although oxygen can infiltrate into the upper vadose zone from the atmosphere. The composition of EVO (SRS; Terra Systems, Wilmington, DE) was (w/w) 60\% vegetable oil, $6 \%$ food grade surfactants, $0.3 \%$ yeast extract, $0.05 \%\left(\mathrm{NH}_{4}\right)_{3} \mathrm{PO}_{4}$, and the remainder was water. An EVO emulsion (680 L EVO diluted to 3,400 L with site groundwater) was evenly injected into the three injection wells on 9 February 2009. Groundwater samples were collected by pumping from W1-W8 before injection and at 4, 17, 31, 80, 140, and 269 days after the injection. For microbial community analysis, groundwater (1 L) was filtered on site with sterile $8 \mu \mathrm{m}$ filters to remove large particles, followed by filtering with $0.2 \mu \mathrm{m}$ filters to collect biomass. The filters were immediately frozen, shipped on dry ice to the laboratory, and stored at $-80^{\circ} \mathrm{C}$ until DNA extraction.

Groundwater Geochemical Analysis. Groundwater samples for metal analysis $(10 \mathrm{~mL})$ were filtered via $0.3 \mu \mathrm{m}$ filters, acidified with $0.05 \mathrm{~mL}$ of concentrated nitric acid, and then stored at $4{ }^{\circ} \mathrm{C}$ until analysis. Details for all analytic methods are described previously. ${ }^{28,29}$ Anions (acetate, $\mathrm{NO}_{3}{ }^{-}, \mathrm{Cl}^{-}$, and $\mathrm{SO}_{4}{ }^{-2}$ ) were analyzed with an ion chromatograph equipped with an IonPac AS-14 analytical column and an AG-14 guard column (Dionex DX-120, Sunnyvale, CA). Cations (e.g., Ag, Ca, Mg, K) were determined using an inductively coupled plasma mass spectrometer (ICPMS) (PerkinElmer ELAN 6100). Aqueous $\mathrm{Fe}(\mathrm{II})$ and total $\mathrm{Fe}$ were measured colorimetrically using a $\mathrm{HACH}$ DR 2000 spectrophotometer (Hach Chemical, Loveland, CO). ${ }^{30}$

DNA Extraction, PCR Amplification, And Pyrosequencing of dsrA Gene Fragments. Primers (DSR1F 5'-ACSCACTGGAAGCACG-3' and DSR2R 5'-GATGTCRTCYYKCCAG-3') were designed to obtain $d s r A$ gene fragments of $\sim 500 \mathrm{bp}$ suitable for pyrosequencing. ${ }^{20}$ DSR2R was reversed from DSR2F and modified so that it provides the highest alignment with $d s r A$ sequences available. Both forward and reverse primers were added with unique 8-mer barcodes, which allowed separate use of either forward or reverse sequences, and combined for longer and greater numbers of sequences as well as improved sequence accuracy and reliability.

The community DNA was extracted using a freeze-grinding method $^{31}$ and quantified with PicoGreen (Quant-It PicoGreen kit; Invitrogen, Carlsbad, CA). DNA template (50 ng) was combined with a PCR mixture containing $2 \mathrm{U}$ AccuPrime highfidelity Taq DNA polymerase (Invitrogen, Carsbad, CA), $10 \mu \mathrm{L}$ buffer containing $2 \mathrm{mM}$ each deoxynucleoside triphosphate, $0.1 \mu \mathrm{M}$ each primer, $2 \mathrm{mM} \mathrm{MgCl}_{2}, 0.1 \mu \mathrm{g} / \mu \mathrm{L}$ bovine serum albumin (New England Biolabs, Beverly, MA), and brought to $100 \mu \mathrm{L}$. DNA samples were amplified in triplicate using the following PCR conditions: $94^{\circ} \mathrm{C}$ for $2 \mathrm{~min}$; $94^{\circ} \mathrm{C}$ for $30 \mathrm{~s}, 54{ }^{\circ} \mathrm{C}$ for $1 \mathrm{~min}$, and $72{ }^{\circ} \mathrm{C}$ for $1 \mathrm{~min}$ for 30 cycles; and $72{ }^{\circ} \mathrm{C}$ for $7 \mathrm{~min}$. PCR products were pooled and purified by agarose gel electrophoresis and bands of $\sim 600 \mathrm{bp}$ were excised. Bands were extracted with a QIAquick gel extraction kit (Qiagen Inc., Valencia, CA) and cleaned with the QIAquick PCR purification kit (Qiagen Inc.). Clean products were quantified with PicoGreen and mixed in equal amounts for 454 pyrosequencing with a Genome Sequencer FLX system (Life Sciences).

Sequence Processing and Statistical Data Analyses. A total of 435725 raw sequences were obtained and low quality sequences were removed using LUCY. ${ }^{32}$ Sequences with lengths less than $200 \mathrm{bp}$ or containing any N's were also removed. Frame shifts caused by sequencing errors were checked using FrameBot (http://fungene.cme.msu.edu/FunGenePipeline/resources/ fbhelp.jsp) and corrected by comparing the obtained sequences to known reference protein sequences. Forward and reverse reads with at least 20-bp overlap and fewer than two mismatches were combined and remaining sequences (254 801) were clustered (UClust, CD-HIT) into candidate OTUs with an identity cutoff of 94\%; the average nucleotide identity was used for microbial species definition in the postgenomic era. ${ }^{33}$ Chimeric sequences were then removed using Chimera Slayer in Qiime. ${ }^{34}$ Singleton reads were also eliminated. ${ }^{35}$ Finally, a random resampling effort of 2000 sequences per sample was performed and data were used for further statistical analysis.

Various statistical approaches were used to analyze the data as described elsewhere. ${ }^{36}$ Hierarchical clustering of all OTUs and samples was used to evaluate differences in SRB community composition and structure. An indicator species approach was used on the resulting clustering topology to find $d s r A$ sequences that represent specific sample clusters. ${ }^{38}$ This method was chosen because it easily deals with high numbers of sequences per sample. It has been used to identify indicator sequences characterizing different bioactivity conditions and the result provides statistical support for the conclusions. ${ }^{12}$ An indicator value (range, 0 to 1 ) was generated for each OTU-sample cluster combination using both frequency of occurrence and relative abundance information. ${ }^{38}$ The indicator value of OTU $i$ in cluster $j$ (e.g., 4-31 days) was calculated as follows:

$$
\text { indicator value } I_{i j}=A_{i j} B_{i j} \text {, and } A_{i j}=\frac{m_{i j}}{\sum_{u=1}^{n} m_{i u}}
$$

where $A_{i j}$ is a measure of specificity of OTU $i$ in cluster $j, m_{i j}$ is the average relative abundance of OTU $i$ cross cluster $j$ samples and is 
calculated as the total relative abundance of OTU $i$ detected in cluster $j$ samples divided by the number of samples in cluster $j . B_{i j}$ is the frequency of occurrence of OTU $i$ in cluster $j$ samples and is calculated as the total number of samples in cluster $j$ that were detected with OTU $i$ divided by the number of samples in cluster $j . n$ is the total cluster number and is 4 in this study.

Other statistical approaches used included (i) microbial diversity indices and significance tests by the Student's $t$ test; (ii) detrended correspondence analysis (DCA) to evaluate differences in key groundwater variables; (iii) analysis of similarity (ANOSIM), permutational multivariate analysis of variance (Adonis), and multiresponse permutation procedure (MRPP) analysis to determine differences in SRB communities; and (iv) canonical correspondence analysis to link SRB community structure with groundwater variables.

\section{RESULTS}

Changes in Key Groundwater Geochemical Variables after EVO Amendment. A detailed description of groundwater geochemical changes was previously reported. ${ }^{26}$ Briefly, EVO amendment stimulated EVO biodegradation and reduction of electron acceptors in the aquifer. Acetate was detected at day 4, increased rapidly, and remained at $\sim 0.5 \mathrm{mM}$ from day 80 to day 140 (SI Figure S1). Sequential reduction of $\mathrm{NO}_{3}{ }^{-}, \mathrm{Mn}(\mathrm{IV})$, $\mathrm{Fe}(\mathrm{III}), \mathrm{U}(\mathrm{VI})$, and $\mathrm{SO}_{4}{ }^{2-}$ was also detected. $\mathrm{NO}_{3}{ }^{-}$decreased within 4 days, and then $\mathrm{Fe}(\mathrm{II})$ and $\mathrm{Mn}$ (II) concentrations increased, indicating $\mathrm{Fe}(\mathrm{III})$ and $\mathrm{Mn}(\mathrm{IV})$ reduction. A decline in $\mathrm{U}(\mathrm{VI})$ was observed later, almost concurrently with a substantial decrease in $\mathrm{SO}_{4}{ }^{2-}$. $\mathrm{U}(\mathrm{VI})$ decreased from $\sim 10$ to $1 \mu \mathrm{M}$ within 24 days. $\mathrm{U}(\mathrm{VI})$ reduction to $\mathrm{U}(\mathrm{IV})$ has been confirmed. ${ }^{26}$ The bioactivity, based on acetate production and $\mathrm{SO}_{4}{ }^{-2}, \mathrm{U}(\mathrm{VI})$, $\mathrm{NO}_{3}{ }^{-}, \mathrm{Fe}(\mathrm{III})$ and $\mathrm{Mn}(\mathrm{IV})$ reduction, increased in $\mathrm{W} 1-\mathrm{W} 7$ after EVO amendment and peaked at days 17-31 (Figure 2).

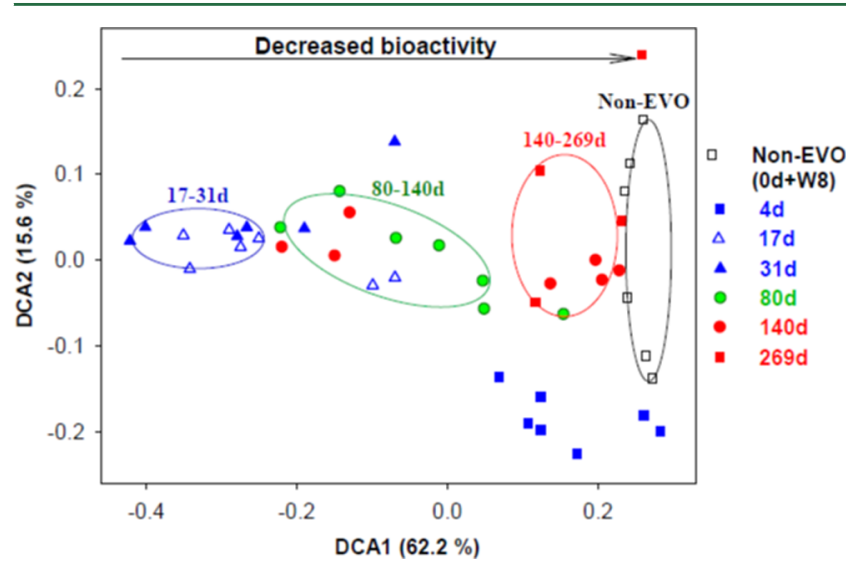

Figure 2. Detrended correspondence analysis (DCA) of groundwater acetate, sulfate, $\mathrm{U}(\mathrm{VI})$, nitrate, $\mathrm{Mn}(\mathrm{II})$, and $\mathrm{Fe}(\mathrm{II})$ concentrations, showing changes in bioactivity in W1 to W7 after EVO amendment. The 44 samples were separated into four major clusters, representing different bioactivity stages based on EVO biodegradation and electron acceptor reduction. The $x$ axis explained a majority (62.2\%) of this variation.

Although the bioactivity declined after 80 days, these redox substrates/products remained detectable at day 269 in some wells. DCA analysis of groundwater acetate, $\mathrm{SO}_{4}{ }^{-2}, \mathrm{U}(\mathrm{VI})$, $\mathrm{NO}_{3}{ }^{-}, \mathrm{Fe}(\mathrm{II})$, and $\mathrm{Mn}(\mathrm{II})$ concentrations suggested that temporal dynamics in bioactivity occurred in W1-W7 after EVO amendment. The 44 samples separated into four major clusters along the first DCA axis which explained $62.2 \%$ of the bioactivity changes, while the changes in W8 were relatively small and along the second axis (15.6\% variations) (Figure 2 ). These clusters represented different bioactivity stages: high bioactivity 1 (17-31 days) (majority of the 17- and 31-day samples), high bioactivity 2 (80-140 days) (majority of the 80 -day samples and three 140-day samples), medium bioactivity (140-269 days) (four 140- and three 269-day samples), and low bioactivity (nonEVO) (two samples respectively collected from W1 and W5 before EVO amendment ( 0 days) and four collected from W8 postamendment $(4,17,31$, and 80 days $))$. The samples at day 4 (W1-W7) were not closely clustered within these major clusters. This may be due primarily to the increased groundwater $\mathrm{U}(\mathrm{VI})$ concentrations at this time point from desorption of $\mathrm{U}(\mathrm{VI})$ from $\mathrm{Fe}(\mathrm{III})$ oxides during the initial $\mathrm{Fe}(\mathrm{III})$ reduction (SI Figure S1). ${ }^{6}$

Shifts in Overall Groundwater SRB Communities after EVO Amendment. A total of $81456 d s r A$ sequences were obtained from 44 samples. The sequences were an average of $\sim 500$ nucleotides in length and separated into 13915 operational taxonomic units (OTUs), with an average of $316 \pm 92$ (from 95 to 436) OTUs per sample. Phylogenetic classification based on BLASTn search identified at a $\geq 80 \%$ similarity level indicated that a majority ( $84 \%)$ of the detected sequences were derived from Deltaproteobacteria, which includes many of the known SRB fatty acid degraders and U(VI) reducers. ${ }^{39}$ Only a small percentage $(0.4 \%)$ of the entire OTU data set were related to Clostridia in Firmicutes, and these included Desulfotomaculumlike sequences found in indigenous groundwater SRB communities at $\mathrm{U}(\mathrm{VI})$-contaminated sites. ${ }^{24}$ However, a considerable portion $(15 \%)$ of the detected sequences remained unknown.

Several statistical analyses of all detected dsrA sequences suggested that EVO amendment stimulated sequential shifts in the overall composition and structure of groundwater SRB communities and increased SRB richness and diversity. Similar shifts in the phylogenetic and functional composition and structure of the overall groundwater microbial communities have been observed. ${ }^{6}$ In the current study, clustering analysis of the detected dsrA sequences separated all samples into four major clusters (Figure 3 and SI Figure S3), and sample groupings were largely consistent with the differences in bioactivity (acetate production and $\mathrm{SO}_{4}{ }^{-2}, \mathrm{U}(\mathrm{VI}), \mathrm{NO}_{3}{ }^{-}, \mathrm{Fe}(\mathrm{III})$ and $\mathrm{Mn}(\mathrm{IV})$ reduction) (Figure 2). The six non-EVO samples formed a major cluster, representing a low bioactivity stage. The EVO-stimulated samples, collected from W1-W7 after EVO amendment, were further separated into three major clusters: (i) 17 out of the 21 4-31 day samples formed a cluster (4-31 days); (ii) five of the seven 80-day and three of the seven 140-day samples formed the majority of a separate cluster (80-140 days); clusters 4-31 days and 80-140 days represented the two high bioactivity stages; (iii) four of the seven 140-day and all four 269-day samples formed the majority of a final cluster (140-269 days), representing a medium bioactivity stage. Also, Shannon-Wiener $\left(H^{\prime}\right)$ and Simpson's $(1 / D)$ diversity indices and OTU numbers were significantly $(P<0.01$ or 0.05$)$ higher in the EVO-stimulated samples than in the non-EVO samples, with higher SRB richness and diversity observed during the active EVO degradation and electron-acceptor reduction period (4-140 days) (SI Figure S4A). Furthermore, three complementary nonparametric multivariate statistical tests (MRPP, Adonis, and ANOSIM) indicated that the composition and structure of groundwater SRB communities underwent major shifts at different bioactivity stages after EVO amendment (non-EVO, 4-31 days, 80-140 days, and 140-269 days, $P<0.001$, SI Table S1), while SRB at different 


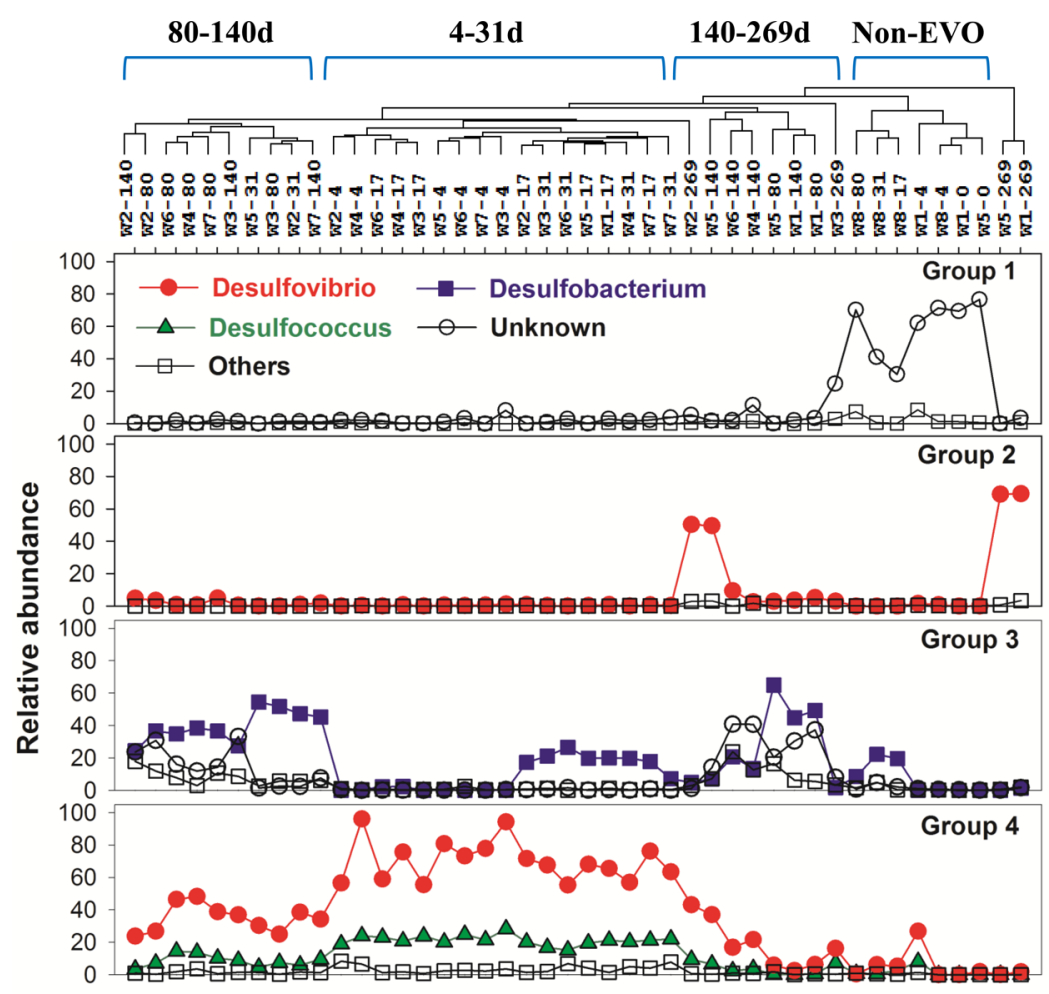

Figure 3. A total of four major groups were observed from clustering of all detected OTUs (SI Figure S3), showing changes in the relative abundance of key SRB after EVO amendment. In the sample identification, the number following the dash indicates the sampling day after EVO amendment, with $0=$ before amendment. Samples are in the same order as that from clustering. Others included OTUs similar to Desulfotomaculum, Desulfosporosinus, and Syntrophobacteraceae.

time points within these major clusters/bioactivity stages were not significantly altered (e.g., 4, 17, 31 days, $P>0.05$ ). As such, for all further statistical analyses of SRB community succession, the samples were grouped into four sets, non-EVO, 4-31 days, 80-140 days, and 140-269 days. We did not obtain PCR products from some samples due to limited DNA, so we used the six non-EVO samples (four of them from W8 collected after EVO amendment) to represent preamendment conditions. Acetate was not detected in W8 over the course of entire experiment suggesting that no significant EVO reached this upgradient control well. ${ }^{6}$ Also, previous analyses indicated that the composition and structure of overall groundwater microbial communities between preamendment and in W8 postamendment was not significantly different. ${ }^{6,40}$

Succession of Key SRB at Different Bioactivity Stages. Clustering analysis separated all detected $d s r A$ sequences into four major groups (SI Figure S3). Group 1 primarily contained unknown sequences, whereas other groups were primarily related to cultured SRB, with group 2 dominated by Desulfovibrio- and group 3 by Desulfobacterium-like sequences (Figure 3). Over half (52\%) of the detected sequences formed group 4 and these sequences were primarily from Desulfovibrio and, to a lesser degree, Desulfococcus species. When these sequence groups were examined further, succession of key SRB at different bioactivity stages was observed. Unknown sequences (group 1) were primarily detected in the non-EVO samples, accounting for up to $80 \%$ of indigenous groundwater SRB communities (SI Figure S5). In contrast, after EVO amendment, sequences related to cultured SRB became abundant in W1-W7, accounting for $83 \pm 13 \%$ of all SRB detected post-EVO amendment. Specifically, at the high bioactivity stage 1 (4-31 days), Desulfovibrio- and Desulfococcuslike sequences were predominant, respectively accounting for
$75 \%$ and $20 \%$ of groundwater SRB. The SRB composition at high bioactivity stage 2 ( $80-140$ days) became more complex. While the abundance of Desulfovibrio and Desulfococcus decreased slightly (40\% and 10\%, respectively), Desulfobacterium spp., which appeared at day 17, were further enriched and became dominant (40-50\%) at this stage. Some minor genera were also detected, including Desulfotomaculum, Desulfosporosinus, and Syntrophobacteraceae. By 140-269 days, these EVO-enriched SRB, particularly Desulfobacterium and Desulfovibrio, were still detected. Also at this later stage, the percentage of unknown sequences increased.

Indicator SRB Characterizing Different Bioactivity Stages. Indicator species analysis of all detected OTUs was performed to quantitatively identify important SRB characterizing the different major clusters and bioactivity stages (SI Figure S3). ${ }^{12,38}$ Indicator values have a maximum of 1 . A value equal to 1 indicates that the OTU is highly abundant in all the samples of a particular cluster and it is unique to this cluster. A value smaller than 1 indicates that the OTU is also present in other clusters. SI Table S2 shows 30 significant indicators that gave the highest indicator values in each major cluster. These results suggest that unknown SRB characterized the communities of non-EVO samples. The top 15 significant indicators of this cluster (values 0.94-1) were rarely detected after EVO amendment (SI Figure S6). In contrast, Desulfovibrio and Desulfococcus were indicators of 4-31 days. The top 15 significant indicators (values $0.65-0.74$ ) were also detected at $80-$ 140 days and 140-269 days despite decreasing in abundances over time, but they were rarely detected in the non-EVO samples (SI Figure S7). Similarly, Desulfobacterium characterized the SRB communities of 80-140 days. The top 15 significant indicators (values $0.63-0.72$ ) appeared at day 17 and were detected through 


\section{4-31d

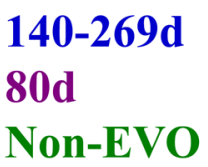

4-31d F4656

4-31d R1953

4-31d FR10

4-31d F1141

4-31d F2052

4-31d R1760

4-31d R1524

4-31d F2247

61 4-31d F2706

90

-4-31d R1920

4-31d F1476

4-31d R1885

61 4-31d R1448 ovorans $\mathrm{Hxd} 3$ 140-269d F2861 140-269d F1889 140-269d F368 140-269d FR7

100 140-269d R459 140-269d FR27 140-269d R399

Desurfovibrio vulgaris - Desulfovibrio 853 Desulfovibrio sp. P1B2 Desulfovibrio simplex

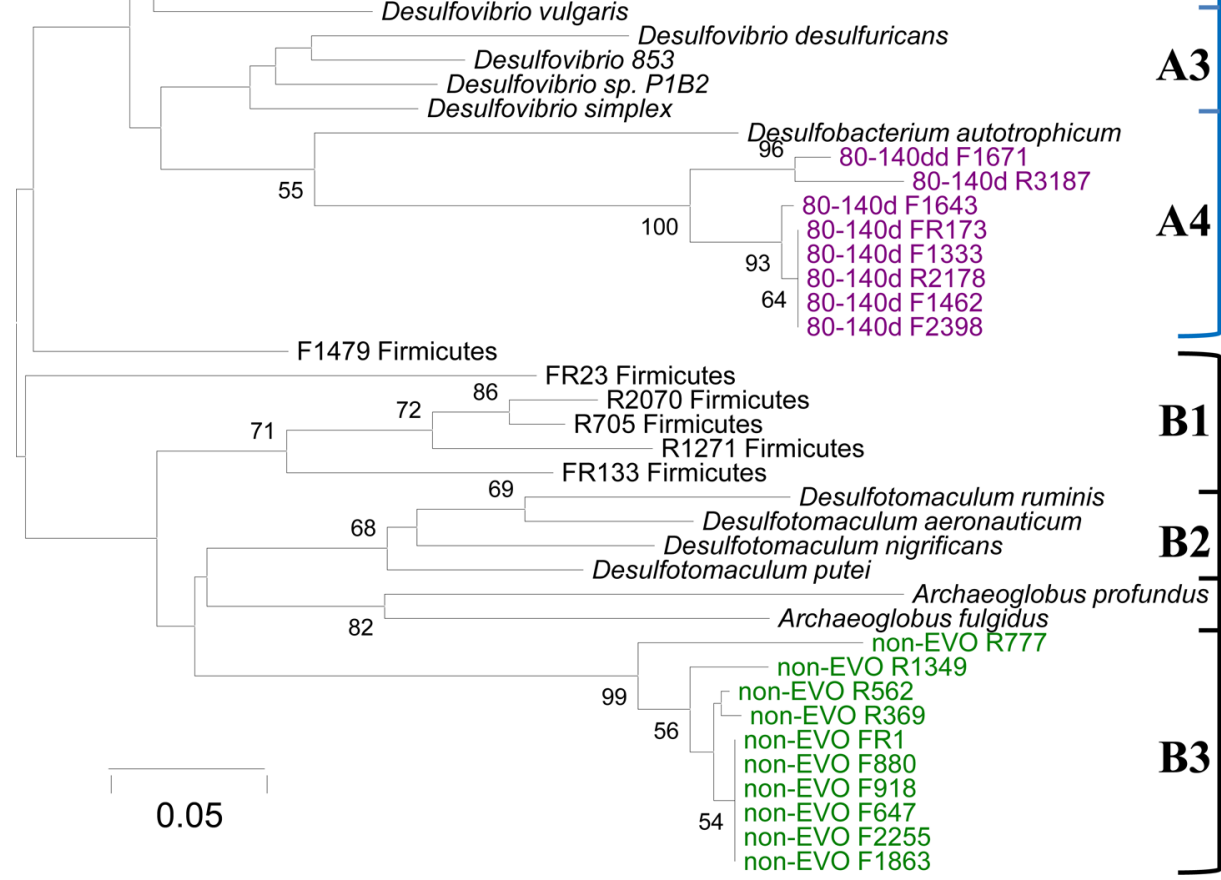

Figure 4. Neighbor-joining analysis of the significant indicators of the four major clusters in SI Figure S5 representing different bioactivity stages. Sequences prefixed with the cluster name "4-31d, 80-140d, 140-269d, or non-EVO" were generated in this study. The prefix is followed by the OTU number. Six dominant Firmicutes-like OTUs (B1) recovered in this study were also included in the analysis. Nucleotide sequence accession numbers are given in parentheses for the following organisms: Desulfovibrio desulfuricans (AJ289157), Desulfovibrio 853 (AY015495), Desulfovibrio simplex (U78738), Desulfovibrio sp. P1B2 (U58116), Desulfobacterium autotrophicum (AF418182), Desulfotomaculum aeronauticum (AY015497), Desulfotomaculum nigrificans (AY015499), Desulfotomaculum putei (AY015498), Desulfotomaculum ruminis (U58118), Desulfococcus oleovorans Hxd3 (AF327308), Desulfovibrio vulgaris Hildenborough (U16723), Archaeoglobus fulgidus (M95624), and Archaeoglobus profundus (AF071499). Archaeoglobus fulgidus and Archaeoglobus profundus are included as the outgroup. The numbers on the tree refer to bootstrap values on 100 replicates; only values above 50 are given. Scale bar represents $5 \%$ estimated change.

269 days (SI Figure S8). Some Desulfovibrio were still among the significant indicators of 140-269 days though Syntrophobacteraceae species were also important at this later stage (SI Figure S9).

Phylogenetic Analysis of Significant Indicator SRB. In order to determine phylogenetic relationships as well as physiological and environmental relevance, the top 15 significant indicators of each cluster (SI Table S2 and Figures S6-S9) were BLASTn-searched against the GenBank database and aligned with known $d s r A$ sequences. We also included sequences from isolates and clones that had relevant physiology (e.g., LCFA degraders, SCFA degraders, $\mathrm{H}_{2}$ oxiders/U(VI) reducers) and/or were from U(VI)-contaminated groundwater. We also included Desulfotomaculum-like sequences recovered in the current study (SI Figure S10) due to this genera's phylogenetic and environmental significance, ${ }^{39}$ such as tolerance to high groundwater
$\mathrm{U}(\mathrm{VI})$ at contaminated sites. ${ }^{24}$ Neighbor-joining analysis revealed the presence of two well-resolved lineages, representing distinct OTUs with (A) and without (B) EVO amendment (Figure 4). Each of these clusters was further divided into subclusters by $<80 \%$ similarity, representing the top 15 significant indicators of different bioactivity stages. Within these subclusters (bioactivity stages), the similarity values were greater $(>85 \%)$.

Three of the top 15 significant indicators of 4-31 days were similar (81-85\%) to Desulfococcus oleovorans Hxd3 known for LCFA degradation (SI Figure S7). Most of the significant indicators of this high bioactivity stage 1 were related $(80-82 \%)$ to Desulfovibrio spp. (subcluster A3), including well-known $\mathrm{U}(\mathrm{VI})$-reducers D. vulgaris and D. desulfuricans, as well as clones (e.g., D. 853) recovered from low-U(VI) groundwater. ${ }^{24}$ Some of the top 15 significant indicators of 140-269 days (A2) were also 
related (78-80\%) to this Desulfovibrio subcluster A3. The top 15 significant indicators of 80-140d formed a subcluster (A4) along with SCFA degraders (e.g., 75\% identity to Desulfobacterium autotrophicum). In contrast, cluster B contained the top 15 significant indicators (subcluster B3) of non-EVO samples. These OTUs were highly divergent from any described species' $d s r A$ sequences $(\sim 73 \%$ identity to an uncultured prokaryote clone only (GU371999.1)), though they formed a general cluster with Desulfotomaculum species and indigenous Desulfotomaculum-like clones (subcluster B2) recovered from contaminated groundwater having $\mathrm{U}(\mathrm{VI})$ similar to the levels at our experimental site. ${ }^{24}$ The Desulfotomaculum-like sequences from the current study (subcluster B1), primarily recovered at later stages (140-269 days) when U(VI) concentrations rebounded (SI Figure S10), were also clustered with this general cluster.

Correlation between SRB Communities and Groundwater Geochemical Variables. Canonical correspondence analysis ${ }^{41}$ was performed to identify the most significant variables shaping the SRB community structure. Based on variation inflation factors (VIFs < 20), 17 groundwater variables were selected, including acetate, $\mathrm{U}(\mathrm{VI}), \mathrm{SO}_{4}{ }^{-2}, \mathrm{NO}_{3}{ }^{-}, \mathrm{Mn}(\mathrm{II})$, and $\mathrm{Fe}(\mathrm{II})$ (SI Figure S11). These variables significantly $(P=0.004)$ explained $62 \%$ of the shifts in the structure of groundwater SRB communities after EVO amendment. Specifically, SRB communities in the non-EVO samples were most significantly correlated with high groundwater $\mathrm{U}(\mathrm{VI}), \mathrm{SO}_{4}{ }^{-2}$, and $\mathrm{NO}_{3}{ }^{-}$concentrations, whereas after EVO amendment, the communities in W1-W7 at the high bioactivity stages (17-140 days) were most significantly correlated with EVO biodegradation (acetate production) and $\mathrm{U}(\mathrm{VI}), \mathrm{SO}_{4}{ }^{-2}, \mathrm{NO}_{3}{ }^{-}, \mathrm{Mn}(\mathrm{IV})$, and $\mathrm{Fe}(\mathrm{III})$ reduction.

\section{DISCUSSION}

Microorganisms are considered the most diverse type of organisms on Earth ${ }^{42}$ and play important roles in various biogeochemical processes, including reduction of $\mathrm{U}(\mathrm{VI})$ in contaminated aquifers. With advances in metagenomic technologies (e.g., highthroughput sequencing, functional gene arrays), novel insights in terms of microbial diversity and responses to environmental perturbations (e.g., substrate amendment) have been obtained. ${ }^{36,40}$ While many of the current $\mathrm{U}(\mathrm{VI})$ reduction studies focused on the diversity, structure and dynamics of overall microbial communities in response to substrate amendment, $6,8,12,27,10$ they have observed stimulation of SRB, both as a group and specific members, during $U(V I)$ reduction as well as significant competition between SRB and other key populations within microbial communities. ${ }^{37,43}$

However, further in-depth analysis of the diversity, composition and structure of individual populations (e.g., SRB) and linking members' dynamics to functional significance (e.g., $\mathrm{U}(\mathrm{VI})$ reduction, substrate degradation) is necessary to better develop strategies to target stimulation of specific ecosystem functions (e.g., maintenance of prolonged U(VI)-reducing conditions). In this study, we examined the diversity, composition and dynamics of groundwater SRB communities in response to EVO amendment. Our results showed that EVO amendment increased the diversity of groundwater SRB and particularly enriched SRB known to participate in LCFA, SCFA, and $\mathrm{H}_{2}$ oxidization and $\mathrm{U}(\mathrm{VI})$ reduction. The results correlated well the dynamics of SRB members with slow EVO degradation, electron donor production and maintenance of $\mathrm{U}(\mathrm{VI})$-reducing conditions in the aquifer.

Our first hypothesis was that amendment and biodegradation of complex EVO would supply a complex mixture of substrates and stimulate the diversity of groundwater SRB. After amendment, EVO is rapidly hydrolyzed into glycerol and LCFAs, which are then biodegraded to propionate, acetate, $\mathrm{H}_{2}$ and $\mathrm{CO}_{2}$. Subsequently, these biodegraded intermediates/products could serve as electron donors and $\mathrm{C}$ sources and stimulate reduction of electron acceptors (U(VI), $\mathrm{NO}_{3}{ }^{-}, \mathrm{SO}_{4}{ }^{2-}, \mathrm{Fe}(\mathrm{III})$, and $\mathrm{Mn}(\mathrm{IV}))$ in the contaminated aquifer. ${ }^{6}$ The presence of abundant substrates would stimulate groundwater microbes including SRB. ${ }^{6}$ SRB are ubiquitous in the environment due to their ability to degrade organic matter ${ }^{44}$ and they are physiologically diverse. They utilize a wide variety of organic substrates and electron donors, including those from EVO hydrolysis/ degradation $^{44-46}$ and are able to reduce various electron acceptors. ${ }^{19,47-50}$ Our $d s r A$ data verified this hypothesis, showing increased diversity and richness of SRB after EVO amendment (SI Figure S4A). The higher diversity and richness at 80140 days was likely associated with the presence of SRB (e.g., Desulfobacterium) degrading EVO breakdown products (e.g., propionate, butyrate) while other microbes including $\mathrm{U}(\mathrm{VI})$ - and LCFA-degrading SRB (e.g., Desulfovibrio, Desulfococcus) decreased in abundance at this later stage (Figure 3). However, our result is in contrast to the decrease in overall diversity and richness of groundwater microbial communities observed by pyrosequencing of the $16 \mathrm{~S}$ rDNA V4 region. ${ }^{6}$ To confirm the lower overall microbial phylogenetic diversity after EVO amendment, we analyzed the $16 \mathrm{~S}$ V4 region by Illumina MiSeq sequencing, which provides more in-depth sequencing and thus improved diversity estimation than pyrosequencing. ${ }^{51}$ Our MiSeq results (SI Figure S4B and C) were consistent with the previous pyrosequencing data, ${ }^{6}$ suggesting that the overall microbial phylogenetic diversity did decrease, with a selective enrichment of a more functionally diverse community of SRB represented primarily by members of Desulfobacteraceae and Desulfovibrionaceae (SI Figure S4D). The more obvious stimulation of overall SRB at early time points (4-31 days) revealed by $d s r A$ sequencing than these dominant SRB families suggested by $16 \mathrm{~S}$ rRNA gene analysis is partially due to differential taxonomic resolution of phylogenetic and functional gene markers. The less highly conserved $d s r A$ offers higher resolution at the species and/or strain level than does sequence variation within the 16S rRNA. This is also consistent with previous pyrosequencing of $d s r A B$ genes, showing that the diversity of SRB in the environment is greater than the predicted via $16 \mathrm{~S}$ rRNA gene analysis alone. ${ }^{52,53}$ GeoChip results of $d s r A B$ genes also suggested stimulation of overall SRB at early time points (4-31 days), consistent with the detected substantial sulfate reduction (SI Figure S1). ${ }^{27,43}$

Our second hypothesis was that EVO amendment would stimulate specific SRB, particularly those related to LCFA degraders, SCFA degraders, $\mathrm{H}_{2}$ consumers and $\mathrm{U}(\mathrm{VI})$ reducers to fully utilize complex EVO and its degradation products. This hypothesis was verified by our observation that Desulfococcus, Desulfobacterium, and Desulfovibrio were dramatically enriched after EVO amendment (Figure 3). Our third hypothesis, namely that the different SRB functional groups would be stimulated at different time points, was also supported. The enrichment and dynamics of these SRB functional groups may be attributed to their distinct physiological and ecological characteristics in relation to complete EVO biodegradation which requires multiple steps (LCFAs, SCFAs, and $\mathrm{H}_{2}$ oxidation). ${ }^{6}$ The abundance of these oxidizers before EVO amendment was presumably low in the oligotrophic groundwater. Although unknown sequences dominated indigenous groundwater SRB communities following 

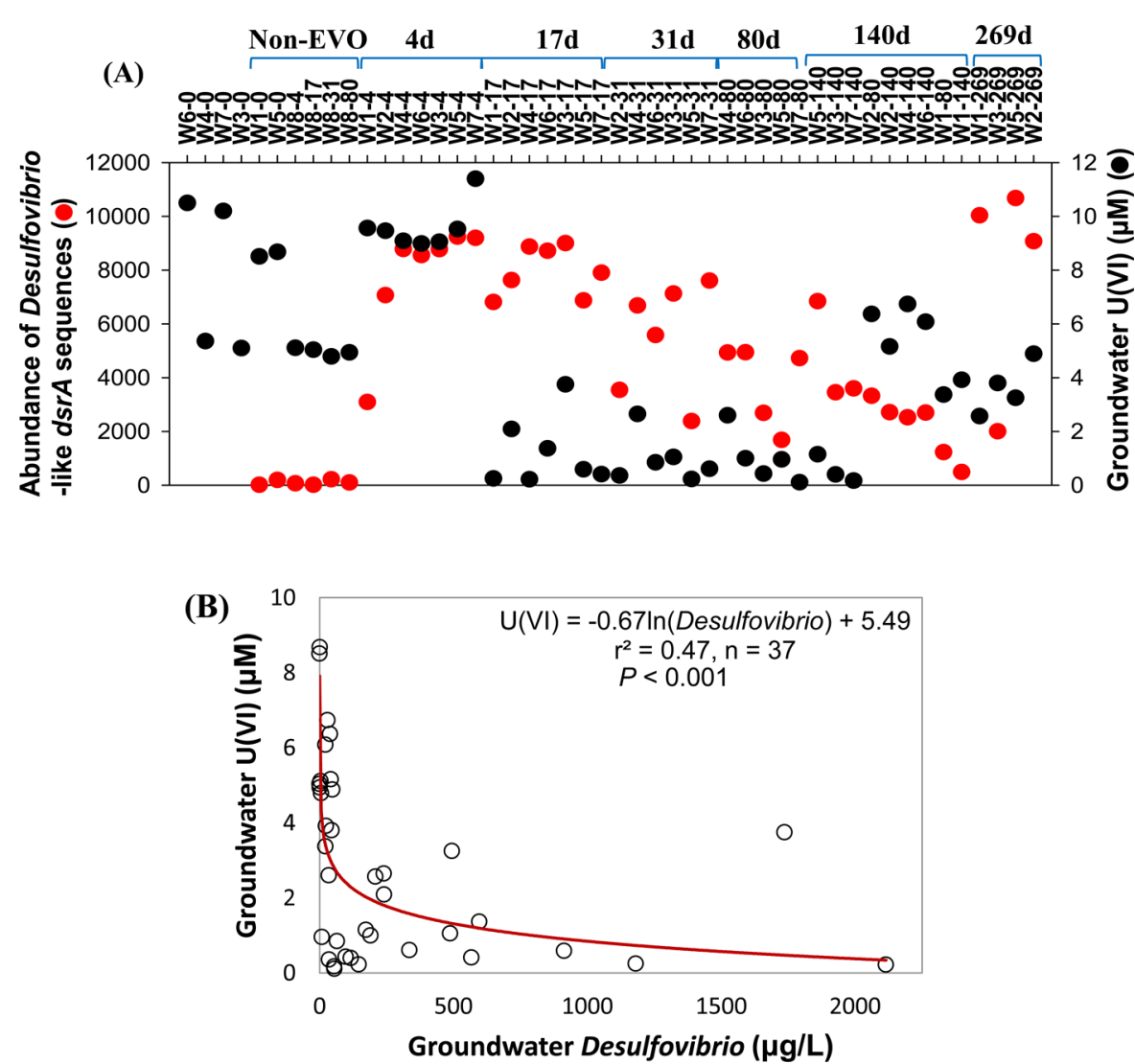

Figure 5. Significant correlations between groundwater Desulfovibrio and U(VI) concentrations: (A) Relative abundance of Desulfovibrio-like dsrA sequences and $\mathrm{U}(\mathrm{VI})$ concentrations in all 44 samples. $\mathrm{U}(\mathrm{VI})$ concentrations from an additional four wells before EVO amendment are also included to show background variations. $d s r A$ amplicons were not obtained from these samples due to limited DNAs. (B) Correlation between groundwater Desulfovibrio ( $\mu \mathrm{g}$ biomass/L) and $\mathrm{U}(\mathrm{VI})$ concentrations. Data from day 4 samples were excluded from analysis due to higher groundwater $\mathrm{U}(\mathrm{VI})$ desorbed from $\mathrm{Fe}$ (III)oxides. The total DNA isolated from per liter of groundwater was used to estimate Desulfovibrio biomass. We assumed that $50 \%$ of the total DNA was from SRB and Desulfovibrio abundance in the total SRB was estimated based on the abundance of Desulfovibrio-like sequences in total sequences detected.

perturbation, the addition of EVO, dominant and rare species may temporally "switch" their positions to cope with the environmental changes. ${ }^{54} \mathrm{An}$ increase of Desulfococcus-like sequences was detected at day 4 . These microbes grow by sulfate reduction coupled with LCFA (such as stearate or palmitate) oxidation. A doubling time of $26 \mathrm{~h}$ has been observed for some strains (e.g., D. oleovorans $\mathrm{Hxd} 3),{ }^{45}$ which would explain their increase after 4 days. Pyrosequencing of $16 \mathrm{~S}$ rRNA genes also indicated stimulation of LCFA degraders, Desulforegula belonging to same general family Desulfobacteraceae. ${ }^{6}$ The difference in genus identified, Desulfococcus vs Desulforegula, is likely due to the moderate sequencing coverage of this pyrosequencing approach. Although a few genera may have been involved in LCFA degradation, these results suggested that specific LCFAdegrading SRB were stimulated shortly after EVO amendment. The slight decline in relative abundance of Desulfococcus-like sequences after 80 days was likely due to the decrease in LCFAs by this time, and could also be due to substantial growth of SCFA (e.g., propionate, butyrate) degraders like Desulfobacterium. These obligate anaerobes grew after 17 days when SCFAs were likely generated (Figure 3 and SI Figure S1). Analysis of $16 \mathrm{~S}$ rRNA genes indicated that Desulfobacteraceae continued to dominate the 80- and 140-day samples. ${ }^{6}$ Our $d s r A$ sequencing revealed that it was SCFA degraders in particular, such as Desulfobacterium-like species in this general family, that were stimulated at this later stage.
In addition to LCFA and SCFA degraders, a large number of Desulfovibrio-like sequences were detected 4 days after EVO amendment and accounted for up to $85 \%$ of the groundwater SRB communities through day 269 (SI Figure S5). Analysis of 16S rRNA genes also detected abundant Desulfovibrionaceae in the groundwater. ${ }^{6}$ These nonfatty-acid degraders could also play a role in complete EVO biodegradation primarily through $\mathrm{H}_{2}$ oxidation. Their early growth (before 4 days) could have been supported by the glycerol that became available immediately after EVO amendment. ${ }^{55-57}$ However, the continued abundance of these Desulfovibrio species could be supported by abundant $\mathrm{H}_{2}$, acetate, and $\mathrm{CO}_{2}$ became available from glycerol, LCFA, and SCFA degradation. ${ }^{5,59}$ Desulfovibrio may be the primary $\mathrm{H}_{2}$ consumers in this system, as SRB outcompete other microbes, such as methanogens, when sulfate is present, as is the case in this subsurface. ${ }^{43,60}$ The $\mathrm{H}_{2}$ consumption, in turn, could play a role in maintaining EVO degradation. ${ }^{44,61}$ Also, Desulfovibrio are able to reduce multiple electron acceptors (e.g., nitrate, $\mathrm{Fe}(\mathrm{III})$ ) in the aquifer. ${ }^{13,47,62,63}$ Thus, the overwhelmingly predominance of Desulfovibrio species after EVO amendment is not unexpected, due to the abundance of usable substrates in the environment and competitive abilities of these microorganisms (e.g., $\mathrm{O}_{2}$ tolerance and reduction). ${ }^{64}$ Overall, previous studies suggested that EVO amendment stimulated only a narrow group of taxa in the groundwater microbial communities including SRB. ${ }^{6}$ Our $d s r A$ analyses were able to further demonstrate that a diverse 
assemblage of SRB participated in the complete degradation of EVO involving a succession of different functional groups at different time points following addition.

We further hypothesized that the dynamic succession of SRB after EVO amendment would promote prolonged U(VI)reducing conditions through slow release of electron donors and $\mathrm{C}$ sources and stimulation of $\mathrm{U}(\mathrm{VI})$-reducing SRB. The abundant Desulfovibrio species in the groundwater could play an important role in U(VI) reduction. Desulfovibrio are well-known metal (e.g., $\mathrm{Fe}(\mathrm{III}), \mathrm{U}(\mathrm{VI}), \mathrm{Cr}(\mathrm{VI})$ ) reducers. All isolates examined to date reduce $\mathrm{U}(\mathrm{VI})$ when suitable electron donors $\left(\mathrm{H}_{2}\right)$ are supplied, ${ }^{6,13,64}$ including $D$. vulgaris $\mathrm{RCH} 1$ isolated from $\mathrm{Cr}$ (VI)-contaminated groundwater (http://www.ncbi.nlm.nih. gov/nuccore/CP002297.1). At this Oak Ridge site, Desulfovibrio-like 16S rDNA sequences ${ }^{12}$ and $d s r A$ mRNA transcripts ${ }^{37}$ were detected during active $\mathrm{U}(\mathrm{VI})$ reduction after biostimulation. The importance of Desulfovibrio species in $\mathrm{U}(\mathrm{VI})$ reduction was further supported by our $d s r A$ data. Groundwater $\mathrm{U}(\mathrm{VI})$ concentrations decreased as the relative abundance of Desulfovibrio-like sequences increased and U(VI) rebounded when Desulfovibrio abundance decreased at later stages (140269 days) (Figure 5A). Groundwater U(VI) concentrations were significantly correlated $\left(P<0.001, r^{2}=0.47\right)$ with Desulfovibrio abundance across 37 samples, with an exception of day 4 samples due to higher U(VI) desorbed from Fe(III)oxides (Figure 5B). ${ }^{6}$ Some Desulfotomaculum-like sequences were also detected at later stages ( $\geq 80$ days), although at much lower abundance than Desulfovibrio (SI Figure S10). A Desulfotomaculum species isolated from marine sediments was able to reduce U(VI) with butyrate as the electron donor. ${ }^{48}$ These microorganisms could have tolerance to groundwater $\mathrm{U}(\mathrm{VI})(>6 \mu \mathrm{M})$ similar to the levels found at our experimental site ${ }^{24}$ and were shown to be active in Oak Ridge sediments during U(VI) reduction based on detection of $d s r A$ mRNA transcripts (37).

The significant indicators (i.e., most abundant and frequently detected sequences) characterizing the different bioactivity stages had $d s r A$ sequences that were $81-85 \%$ similar to those of known LCFA degraders, SCFA degraders, $\mathrm{H}_{2}$ consumers and $\mathrm{U}(\mathrm{VI})$ reducers. These sequences could play important roles in EVO degradation and $\mathrm{U}(\mathrm{VI})$ reduction as dominant species are often found to be functionally important and could contribute more to community performance and ecosystem functions. ${ }^{54}$ Although none of these significant indicators were identical to isolates having relevant physiology, nor to the limited number of clones (e.g., Desulfovibrio 853) previously obtained from indigenous groundwater SRB communities at U(VI)-contaminated sites, ${ }^{24}$ more recent studies indicated that the Desulfovibriolike significant indicators of the active $\mathrm{U}(\mathrm{VI})$ reduction period (4-31 days) (SI Figure S7) were highly similar (96-99\%) to a number of uncultured clones recovered from a fixed-bed bioreactor system undergoing arsenate reduction. ${ }^{65}$ In that system, substrate amendment stimulated the development of a sequence of terminal electron-accepting process zones $\left(\mathrm{O}_{2}\right.$, nitrate, arsenate and sulfate reduction) along the water flow path. Microorganisms formed biofilms on the fixed-bed surface to minimize washout of active species, such as Desulfovibrio. ${ }^{65} \mathrm{~A}$ similar process could be occurring in our fast-flowing aquifer. We anticipate that further analysis of groundwater and sediment samples following amendment of different substrates (acetate, ethanol, glycerol polylactate and EVO) will reveal much greater sequence diversity, pointing to a complex ecology of SRB in the subsurface and mechanisms of prolonged $\mathrm{U}(\mathrm{VI}) / \mathrm{Cr}(\mathrm{VI})$ reduction at the DOE sites.
In summary, this study used pyrosequencing of $d s r A$ gene amplicons to analyze groundwater SRB community dynamics in response to EVO amendment during prolonged U(VI)-reducing conditions. Results showed that EVO amendment increased the functional diversity of groundwater SRB and particularly enriched functional groups important in LCFA, SCFA, and $\mathrm{H}_{2}$ oxidization and $\mathrm{U}(\mathrm{VI})$ reduction. We examined one of the key populations known to be enriched after substrate amendment. ${ }^{6}$ While nitrate- and $\mathrm{Fe}$ (III)-reducing bacteria are known to be important in nitrate removal and early U(VI) reduction, ${ }^{6}$ our data showed that the dynamic succession of SRB promotes prolonged $\mathrm{U}(\mathrm{VI})$-reducing conditions through slow EVO degradation, supplying electron donors and stimulating U(VI) reducers. Desulfovibrio could be an important player and $\mathrm{HS}^{-}$ from sulfate reduction may also play a significant role in the indirect reduction of $\mathrm{U}(\mathrm{VI})$ in this experiment. $6,66,67,68$ This study improves our understanding on the diversity and dynamics of SRB participating in substrate degradation and $\mathrm{U}(\mathrm{VI})$ reduction and provides mechanistic insights on how SRB community succession promotes prolonged $\mathrm{U}(\mathrm{VI})$-reducing conditions. Our analysis identified some key $d s r A$ sequences, and results suggested that long-term stimulation of these key SRBs may sustain $\mathrm{U}(\mathrm{VI})$ reduction. Given that SRBs are versatile in terms of reduction/degradation of environmental contaminants both heavy metals and organics (e.g., $\mathrm{Cr}(\mathrm{VI})$, arsenic, technetium, petroleum), the knowledge gained from examining the U(VI)-reducing community should be useful in the design of future strategies for long-term contaminant attenuation of various sites.

\section{ASSOCIATED CONTENT}

\section{Supporting Information}

The Supporting Information is available free of charge on the ACS Publications website at DOI: 10.1021/acs.est.6b02980.

Detailed description of all methods, groundwater chemical concentrations, hierarchical clustering of all OTUs and significant indicator OTUs for control and EVO samples at different time points, diversity indices for $16 \mathrm{~S}$ and $d s r A$ sequences, relative abundance of detected genera, and CCA of detected OTUs and environmental parameter, dissimilarity analysis results and a list of significant indicator OTUs (PDF)

\section{AUTHOR INFORMATION}

\section{Corresponding Author}

*Phone: (405) 325-6073; fax: (405) 325-7552; e-mail: jzhou@ ou.edu.

ORCID $\odot$

Ping Zhang: 0000-0002-9455-2265

Jianjun Wang: 0000-0001-7039-7136

Matthew W. Fields: 0000-0001-9053-1849

\section{Present Address}

(P.Z.) Sequencing and Microarray Facility and Department of Genetics, University of Texas MD Anderson Cancer Center, Houston, Texas 77081, United States.

\section{Author Contributions}

This manuscript has been authored by Lawrence Berkeley National Lab under Contract No. DE-AC02-05CH11231 with the U.S. Department of Energy. The United States Government retains and the publisher, by accepting the article for publication, acknowledges that the United States Government retains a 
nonexclusive, paid-up, irrevocable, worldwide license to publish or reproduce the published form of this manuscript, or allow others to do so, for United States Government purposes.

\section{Notes}

The authors declare no competing financial interest.

\section{ACKNOWLEDGMENTS}

The field sampling was supported by the Subsurface Biogeochemical Research Program under Contract No. DE-FG0207ER64398, and microbial community analysis was supported by ENIGMA-Ecosystems and Networks Integrated with Genes and Molecular Assemblies, a Scientific Focus Area Program at Lawrence Berkeley National Laboratory, under Contract No. DE-AC02-05CH11231 through the Office of Science, Office of Biological and Environmental Research, of the US Department of Energy.

\section{REFERENCES}

(1) Abdelouas, A.; Lutze, W.; Nuttall, H. E. Uranium Contamination in the Subsurface: Characterization and Remediation. Rev. Mineral. 1999, $38,433-473$.

(2) Lovley, D. R.; Phillips, E. J. P.; Gorby, Y. A.; Landa, E. R. Microbial Reduction of Uranium. Nature 1991, 350 (6317), 413-416.

(3) Fruchter, J. In situ treatment of chromium-contaminated groundwater. Environ. Sci. Technol. 2002, 36 (23), 464a-472a.

(4) Wall, J. D.; Krumholz, L. R. Uranium reduction. Annu. Rev. Microbiol. 2006, 60, 149-166.

(5) Anderson, R. T.; Vrionis, H. A.; Ortiz-Bernad, I.; Resch, C. T.; Long, P. E.; Dayvault, R.; Karp, K.; Marutzky, S.; Metzler, D. R.; Peacock, A.; White, D. C.; Lowe, M.; Lovley, D. R. Stimulating the in situ activity of Geobacter species to remove uranium from the groundwater of a uranium-contaminated aquifer. Appl. Environ. Microb 2003, 69 (10), 5884-5891.

(6) Gihring, T. M.; Zhang, G. X.; Brandt, C. C.; Brooks, S. C.; Campbell, J. H.; Carroll, S.; Criddle, C. S.; Green, S. J.; Jardine, P.; Kostka, J. E.; Lowe, K.; Mehlhorn, T. L.; Overholt, W.; Watson, D. B.; Yang, Z. M.; Wu, W. M.; Schadt, C. W. A Limited Microbial Consortium Is Responsible for Extended Bioreduction of Uranium in a Contaminated Aquifer. Appl. Environ. Microb 2011, 77 (17), 59555965.

(7) North, N. N.; Dollhopf, S. L.; Petrie, L.; Istok, J. D.; Balkwill, D. L.; Kostka, J. E. Change in bacterial community structure during in situ Biostimulation of subsurface sediment cocontaminated with uranium and nitrate. Appl. Environ. Microb 2004, 70 (8), 4911-4920.

(8) Cardenas, E.; Wu, W. M.; Leigh, M. B.; Carley, J.; Carroll, S.; Gentry, T.; Luo, J.; Watson, D.; Gu, B.; Ginder-Vogel, M.; Kitanidis, P. K.; Jardine, P. M.; Zhou, J.; Criddle, C. S.; Marsh, T. L.; Tiedje, J. A. Microbial communities in contaminated sediments, associated with bioremediation of uranium to submicromolar levels. Appl. Environ. Microb 2008, 74 (12), 3718-3729.

(9) Faybishenko, B.; Hazen, T. C.; Long, P. E.; Brodie, E. L.; Conrad, M. E.; Hubbard, S. S.; Christensen, J. N.; Joyner, D.; Borglin, S. E.; Chakraborty, R.; Williams, K. H.; Peterson, J. E.; Chen, J. S.; Brown, S. T.; Tokunaga, T. K.; Wan, J. M.; Firestone, M.; Newcomer, D. R.; Resch, C. T.; Cantrell, K. J.; Willett, A.; Koenigsberg, S. In Situ Long-Term Reductive Bioimmobilization of $\mathrm{Cr}(\mathrm{VI})$ in Groundwater Using Hydrogen Release Compound. Environ. Sci. Technol. 2008, 42 (22), 8478-8485.

(10) Kwon, M. J.; O'Loughlin, E. J.; Boyanov, M. I.; Brulc, J. M.; Johnston, E. R.; Kemner, K. M.; Antonopoulos, D. A. Impact of Organic Carbon Electron Donors on Microbial Community Development under Iron- and Sulfate-Reducing Conditions. PLoS One 2016, 11 (1), e0146689.

(11) Hwang, C. C.; Wu, W. M.; Gentry, T. J.; Carley, J.; Corbin, G. A.; Carroll, S. L.; Watson, D. B.; Jardine, P. M.; Zhou, J. Z.; Criddle, C. S.; Fields, M. W. Bacterial community succession during in situ uranium bioremediation: spatial similarities along controlled flow paths. ISME J. 2009, 3 (1), 47-64.

(12) Marsh, T. L.; Cardenas, E.; Wu, W. M.; Leigh, M. B.; Carley, J.; Carroll, S.; Gentry, T.; Luo, J.; Watson, D.; Gu, B. H.; Ginder-Vogel, M.; Kitanidis, P. K.; Jardine, P. M.; Zhou, J. Z.; Criddle, C. S.; Tiedje, J. M. Significant Association between Sulfate-Reducing Bacteria and Uranium-Reducing Microbial Communities as Revealed by a Combined Massively Parallel Sequencing-Indicator Species Approach. Appl. Environ. Microb 2010, 76 (20), 6778-6786.

(13) Lovley, D. R.; Roden, E. E.; Phillips, E. J. P.; Woodward, J. C. Enzymatic Iron and Uranium Reduction by Sulfate-Reducing Bacteria. Mar. Geol. 1993, 113 (1-2), 41-53.

(14) Zhou, J.; Qiang, H.; Hemme, C. L.; Mukhopadhyay, A.; Hillesland, K.; Zhou, A.; He, Z.; Van Nostrand, J. D.; Hazen, T. C.; Stahl, D. A.; Wall, J. D.; Arkin, A. P. How Sulfate Reducing Microorganisms Cope with Stress: Lessons from Systems Biology. Nat. Rev. Microbiol. 2011, 20119, 452-466.

(15) Barlett, M.; Zhuang, K.; Mahadevan, R.; Lovley, D. Integrative Analysis of Geobacter spp. and Sulfate-Reducing Bacteria During Uranium Bioremediation. Biogeosciences 2012, 9, 1033-1040.

(16) Miletto, M.; Williams, K. H.; N’Guessan, A. L.; Lovley, D. R. Molecular Analysis of the Metabolic Rates of Discrete Subsurface Populations of Sulfate Reducers. Appl. Environ. Microbiol. 2011, 77 (18), 6502-6509.

(17) McGuinness, L. R.; Wilkins, M. J.; Williams, K. H.; Long, P. E.; Kerkhof, L. J. 2015. Identification of Bacteria Synthesizing Ribosomal RNA in Response to Uranium Addition During Biostimulation at the Rifle, CO Integrated Field Research Site. PLoS One 2015, 10, e0137270.

(18) Boonchayaanant, B.; Gu, B.; Wang, W.; Ortiz, M. E.; Criddle, C. S. Can Microbially-Generated Hydrogen Sulfide Account for the Rates of U(VI) Reduction by a Sulfate-Reducing Bacterium? Biodegradation 2010, 21, 81 .

(19) Lovley, D. R.; Phillips, E. J. P. Reduction of Chromate by Desulfovibrio-Vulgaris and Its C(3) Cytochrome. Appl. Environ. Microb. 1994, 60 (2), 726-728.

(20) Wagner, M.; Roger, A. J.; Flax, J. L.; Brusseau, G. A.; Stahl, D. A. Phylogeny of dissimilatory sulfite reductases supports an early origin of sulfate respiration. J. Bacteriol. 1998, 180 (11), 2975-2982.

(21) Karr, E. A.; Sattley, W. M.; Rice, M. R.; Jung, D. O.; Madigan, M. T.; Achenbach, L. A. Diversity and distribution of sulfate-reducing bacteria in permanently frozen Lake Fryxell, McMurdo Dry Valleys, Antarctica. Appl. Environ. Microb 2005, 71 (10), 6353-9.

(22) Liu, X. D.; Bagwell, C. E.; Wu, L. Y.; Devol, A. H.; Zhou, J. H. Molecular diversity of sulfate-reducing bacteria from two different continental margin habitats. Appl. Environ. Microb 2003, 69 (10), 60736081.

(23) Perez-Jimenez, J. R.; Kerkhof, L. J. Phylogeography of sulfatereducing bacteria among disturbed sediments, disclosed by analysis of the dissimilatory sulfite reductase genes (dsrAB). Appl. Environ. Microb 2005, 71 (2), 1004-1011.

(24) Chang, Y. J.; Peacock, A. D.; Long, P. E.; Stephen, J. R.; McKinley, J. P.; Macnaughton, S. J.; Hussain, A. K.; Saxton, A. M.; White, D. C. Diversity and characterization of sulfate-reducing bacteria in groundwater at a uranium mill tailings site. Appl. Environ. Microbiol. 2001, 67 (7), 3149-60

(25) Miletto, M.; Williams, K. H.; N'Guessan, A. L.; Lovley, D. R. Molecular Analysis of the Metabolic Rates of Discrete Subsurface Populations of Sulfate Reducers. Appl. Environ. Microb 2011, 77 (18), 6502-6509.

(26) Frank, K. L.; Rogers, D. R.; Olins, H. C.; Vidoudez, C.; Girguis, P. $\mathrm{R}$. Characterizing the distribution and rates of microbial sulfate reduction at Middle Valley hydrothermal vents. ISME J. 2013, 7 (7), 1391-1401.

(27) Watson, D. B.; Wu, W. M.; Mehlhorn, T.; Tang, G.; Earles, J.; Lowe, K.; Gihring, T. M.; Zhang, G.; Phillips, J.; Boyanov, M. I.; Spalding, B. P.; Schadt, C.; Kemner, K. M.; Criddle, C. S.; Jardine, P. M.; Brooks, S. C. In situ bioremediation of uranium with emulsified vegetable oil as the electron donor. Environ. Sci. Technol. 2013, 47 (12), $6440-8$. 
(28) Zhang, P.; Wu, W. M.; Van Nostrand, J. D.; Deng, Y.; He, Z.; Gihring, T.; Zhang, G.; Schadt, C. W.; Watson, D.; Jardine, P.; Criddle, C. S.; Brooks, S.; Marsh, T. L.; Tiedje, J. M.; Arkin, A.; Zhou, J. Dynamic succession of groundwater functional microbial communities in response to emulsified vegetable oil amendment during sustained in situ U(VI) reduction. Appl. Environ. Microbiol. 2015, 81, 4164-4172.

(29) Wu, W. M.; Carley, J.; Green, S. J.; Luo, J.; Kelly, S. D.; Van Nostrand, J.; Lowe, K.; Mehlhorn, T.; Carroll, S.; Boonchayanant, B.; Lofller, F. E.; Watson, D.; Kemner, K. M.; Zhou, J. Z.; Kitanidis, P. K.; Kostka, J. E.; Jardine, P. M.; Criddle, C. S. Effects of Nitrate on the Stability of Uranium in a Bioreduced Region of the Subsurface. Environ. Sci. Technol. 2010, 44 (13), 5104-5111.

(30) Wu, W. M.; Carley, J.; Luo, J.; Ginder-Vogel, M. A.; Cardenas, E.; Leigh, M. B.; Hwang, C. C.; Kelly, S. D.; Ruan, C. M.; Wu, L. Y.; Van Nostrand, J.; Gentry, T.; Lowe, K.; Mehlhorn, T.; Carroll, S.; Luo, W. S.; Fields, M. W.; Gu, B. H.; Watson, D.; Kemner, K. M.; Marsh, T.; Tiedje, J.; Zhou, J. Z.; Fendorf, S.; Kitanidis, P. K.; Jardine, P. M.; Criddle, C. S. In situ bioreduction of uranium (VI) to submicromolar levels and reoxidation by dissolved oxygen. Environ. Sci. Technol. 2007, 41 (16), $5716-5723$.

(31) Viollier, E.; Inglett, P. W.; Hunter, K.; Roychoudhury, A. N.; Van Cappellen, P. The ferrozine method revisited: $\mathrm{Fe}(\mathrm{II}) / \mathrm{Fe}(\mathrm{III})$ determination in natural waters. Appl. Geochem. 2000, 15 (6), 785-790.

(32) Zhou, J. Z.; Bruns, M. A.; Tiedje, J. M. DNA recovery from soils of diverse composition. Appl. Environ. Microb. 1996, 62 (2), 316-322.

(33) Chou, H. H.; Holmes, M. H. DNA sequence quality trimming and vector removal. Bioinformatics 2001, 17 (12), 1093-1104.

(34) Konstantinidis, K. T.; Tiedje, J. M. Genomic insights that advance the species definition for prokaryotes. Proc. Natl. Acad. Sci. U. S. A. 2005, 102 (7), 2567-2572.

(35) Haas, B. J.; Gevers, D.; Earl, A. M.; Feldgarden, M.; Ward, D. V.; Giannoukos, G.; Ciulla, D.; Tabbaa, D.; Highlander, S. K.; Sodergren, E.; Methe, B.; DeSantis, T. Z.; Petrosino, J. F.; Knight, R.; Birren, B. W. Consortium, H. M. Chimeric 16S rRNA sequence formation and detection in Sanger and 454-pyrosequenced PCR amplicons. Genome Res. 2011, 21 (3), 494-504.

(36) Zhou, J.; Wu, L.; Deng, Y.; Zhi, X.; Jiang, Y. H.; Tu, Q.; Xie, J.; Van Nostrand, J. D.; He, Z.; Yang, Y. Reproducibility and quantitation of amplicon sequencing-based detection. ISME J. 2011, 5 (8), 1303-13.

(37) He, Z. L.; Xu, M. Y.; Deng, Y.; Kang, S. H.; Kellogg, L.; Wu, L. Y.; Van Nostrand, J. D.; Hobbie, S. E.; Reich, P. B.; Zhou, J. Z. Metagenomic analysis reveals a marked divergence in the structure of belowground microbial communities at elevated CO2. Ecol Lett. 2010, 13 (5), 564575.

(38) Akob, D. M.; Lee, S. H.; Sheth, M.; Küsel, K.; Watson, D. B.; Palumbo, A. V.; Kostka, J. E.; Chin, K. J. 2012. Gene expression correlates with process rates quantified for sulfate- and $\mathrm{Fe}$ (III)-reducing bacteria in U(VI)-contaminated sediments. Front. Microbiol. 2012, 3, 00280 .

(39) Dufrene, M.; Legendre, P. Species assemblages and indicator species: The need for a flexible asymmetrical approach. Ecol. Monogr. 1997, 67 (3), 345-366.

(40) Muyzer, G.; Stams, A. J. M. The ecology and biotechnology of sulphate-reducing bacteria. Nat. Rev. Microbiol. 2008, 6 (6), 441-454.

(41) Zhou, J. Z.; Deng, Y.; Zhang, P.; Xue, K.; Liang, Y. T.; Van Nostrand, J. D.; Yang, Y. F.; He, Z. L.; Wu, L. Y.; Stahl, D. A.; Hazen, T. C.; Tiedje, J. M.; Arkin, A. P. Stochasticity, succession, and environmental perturbations in a fluidic ecosystem. Proc. Natl. Acad. Sci. U. S. A. 2014, 111 (9), E836-E845.

(42) Daly, K.; Sharp, R. J.; McCarthy, A. J. Development of oligonucleotide probes and PCR primers for detecting phylogenetic subgroups of sulfate-reducing bacteria. Microbiology 2000, 146 (Pt 7), $1693-705$.

(43) Venter, J. C.; Remington, K.; Heidelberg, J. F.; Halpern, A. L.; Rusch, D.; Eisen, J. A.; Wu, D. Y.; Paulsen, I.; Nelson, K. E.; Nelson, W.; Fouts, D. E.; Levy, S.; Knap, A. H.; Lomas, M. W.; Nealson, K.; White, O.; Peterson, J.; Hoffman, J.; Parsons, R.; Baden-Tillson, H.; Pfannkoch, C.; Rogers, Y. H.; Smith, H. O. Environmental genome shotgun sequencing of the Sargasso Sea. Science 2004, 304 (5667), 66-74.
(44) Deng, Y.; Zhang, P.; Qin, Y.; Tu, Q.; Yang, Y.; He, Z.; Schadt, C. W.; Zhou, J. Network succession reveals the importance of competition in response to emulsified vegetable oil amendment for uranium bioremediation. Environ. Microbiol. 2016, 18, 205-218.

(45) Jackson, B. E.; Bhupathiraju, V. K.; Tanner, R. S.; Woese, C. R.; McInerney, M. J. Syntrophus aciditrophicus sp. nov., a new anaerobic bacterium that degrades fatty acids and benzoate in syntrophic association with hydrogen-using microorganisms. Arch. Microbiol. 1999, 171 (2), 107-14.

(46) Aeckersberg, F.; Bak, F.; Widdel, F. Anaerobic Oxidation of Saturated-Hydrocarbons to Co2 by a New Type of Sulfate-Reducing Bacterium. Arch. Microbiol. 1991, 156 (1), 5-14.

(47) Janssen, P. H.; Schink, B. Pathway of Butyrate Catabolism by Desulfobacterium-Cetonicum. J. Bacteriol. 1995, 177 (13), 3870-3872.

(48) Lovley, D. R.; Phillips, E. J. P. Reduction of Uranium by Desulfovibrio-Desulfuricans. Appl. Environ. Microb. 1992, 58 (3), 850856.

(49) Tebo, B. M.; Obraztsova, A. Y. Sulfate-reducing bacterium grows with $\mathrm{Cr}(\mathrm{VI}), \mathrm{U}(\mathrm{VI}), \mathrm{Mn}(\mathrm{IV})$, and $\mathrm{Fe}(\mathrm{III})$ as electron acceptors. FEMS Microbiol. Lett. 1998, 162 (1), 193-198.

(50) Suzuki, Y.; Kelly, S. D.; Kemner, K. M.; Banfield, J. F. Microbial populations stimulated for hexavalent uranium reduction in uranium mine sediment. Appl. Environ. Microbiol. 2003, 69 (3), 1337-46.

(51) Suzuki, Y.; Kelly, S. D.; Kemner, K. M.; Banfield, J. F. Enzymatic $\mathrm{U}(\mathrm{VI})$ reduction by Desulfosporosinus species. Radiochim. Acta 2004, 92 (1), 11-16.

(52) Loman, N. J.; Misra, R. V.; Dallman, T. J.; Constantinidou, C.; Gharbia, S. E.; Wain, J.; Pallen, M. J. Performance comparison of benchtop high-throughput sequencing platforms. Nat. Biotechnol. 2012, 30 (5), 434.

(53) Nercessian, O.; Bienvenu, N.; Moreira, D.; Prieur, D.; Jeanthon, C. Diversity of functional genes of methanogens, methanotrophs and sulfate reducers in deep-sea hydrothermal environments. Environ. Microbiol. 2005, 7 (1), 118-32.

(54) Nakagawa, T.; Nakagawa, S.; Inagaki, F.; Takai, K.; Horikoshi, K. Phylogenetic diversity of sulfate-reducing prokaryotes in active deep-sea hydrothermal vent chimney structures. FEMS Microbiol. Lett. 2004, 232 (2), 145-52.

(55) Walker, B.; Kinzig, A.; Langridge, J. Plant attribute diversity, resilience, and ecosystem function: The nature and significance of dominant and minor species. Ecosystems 1999, 2 (2), 95-113.

(56) Nanninga, H. J.; Gottschal, J. C. Properties of DesulfovibrioCarbinolicus Sp-Nov and Other Sulfate-Reducing Bacteria Isolated from an Anaerobic-Purification Plant. Appl. Environ. Microb. 1987, 53 (4), 802-809.

(57) Gam, Z. B.; Oueslati, R.; Abdelkafi, S.; Casalot, L.; Tholozan, J. L.; Labat, M. Desulfovibrio tunisiensis sp nov., a novel weakly halotolerant, sulfate-reducing bacterium isolated from exhaust water of a Tunisian oil refinery. Int. J. Syst. Evol. Microbiol. 2009, 59, 1059-1063.

(58) Qatibi, A. I.; Bories, A.; Garcia, J. L. Sulfate Reduction and Anaerobic Glycerol Degradation by a Mixed Microbial Culture. Curr. Microbiol. 1991, 22 (1), 47-52.

(59) Badziong, W.; Thauer, R. K.; Zeikus, J. G. Isolation and Characterization of Desulfovibrio Growing on Hydrogen Plus Sulfate as Sole Energy-Source. Arch. Microbiol. 1978, 116 (1), 41-49.

(60) Brandis, A.; Thauer, R. K. Growth of Desulfovibrio Species on Hydrogen and Sulfate as Sole Energy-Source. Microbiology 1981, 126 (Sep), 249-252.

(61) Sousa, D. Z.; Alves, J. I.; Alves, M. M.; Smidt, H.; Stams, A. J. M. Effect of sulfate on methanogenic communities that degrade unsaturated and saturated long-chain fatty acids (LCFA). Environ. Microbiol. 2009, 11 (1), 68-80.

(62) Sousa, D. Z.; Pereira, M. A.; Stams, A. J. M.; Alves, M. M.; Smidt, H. Microbial communities involved in anaerobic degradation of unsaturated or saturated long-chain fatty acids. Appl. Environ. Microb 2007, 73 (4), 1054-1064.

(63) Voordouw, G. The Genus Desulfovibrio - the Centennial. Appl. Environ. Microb. 1995, 61 (8), 2813-2819. 
(64) Cypionka, H. Oxygen respiration by Desulfovibrio species. Annu. Rev. Microbiol. 2000, 54, 827-848.

(65) Lovley, D. R.; Widman, P. K.; Woodward, J. C.; Phillips, E. J. P. Reduction of Uranium by Cytochrome-C(3) of Desulfovibrio-Vulgaris. Appl. Environ. Microb. 1993, 59 (11), 3572-3576.

(66) Upadhyaya, G.; Clancy, T. M.; Brown, J.; Hayes, K. F.; Raskin, L. Optimization of Arsenic Removal Water Treatment System through Characterization of Terminal Electron Accepting Processes. Environ. Sci. Technol. 2012, 46 (21), 11702-11709.

(67) Hyun, S. P.; Davis, J. A.; Hayes, K. F. Abiotic U(VI) reduction by aqueous sulfide. Appl. Geochem. 2014, 50, 7-15.

(68) Zhou, C.; Vannela, R.; Hayes, K. F.; Hyun, S. P.; Rittmann, B. E. 2014. Growth of Desulfovibrio vulgaris when Respiring U(VI) and Characterization of Biogenic Uraninite. Environ. Sci. Technol. 2014, 48, 6928-6937. 